\title{
Paradoks pluralizmu: Absorpcja i marginalizacja mniejszości
}

\author{
The Paradox of Pluralism: The Absorption \\ and Marginalization of Minorities
}

\author{
Sara Burchert ${ }^{\star}$
}

\begin{abstract}
Abstrakt
Artykuł dotyczy pluralizmu i pozornego pluralizmu w demokracji. Analiza mechanizmów absorpcji i marginalizacji grup mniejszościowych, ich interesów i uczestnictwa w dyskursie publicznym, sposobów i możliwości artykulacji stanowisk im bliskich, pozwala na scharakteryzowanie zależności i elementów wpływających na jakość i możliwość zaistnienia pluralistycznego społeczeństwa. Istotą funkcjonowania wizji pluralistycznej debaty staje się nadawanie temu, co zastane, znamion różnorodności. Ważna jest również analiza sytuacji medialnej - strukturalnych, przestrzennych, a także finansowych ograniczeń, które stanowią argument już znaturalizowany i zaakceptowany, co do którego nie powinno się toczyć sporów. W ten sposób dwustronnie moderuje się wolną dyskusję, gdzie niemający do niej
\end{abstract}

\begin{abstract}
In her article, Sara Burchert is concerned with pluralism and illusory pluralism in democracy. She analyses the mechanisms of the absorption and marginalization of minority groups, their interests, and their participation in public discourse, the ways and possibilities of articulating positions which are close to them in order to identify elements which make possible a pluralistic society and determine its quality. Essential for the functioning of the vision of a pluralistic debate is the bestowing of marks of diversity on what is present. It is also important to analyze the media situation - structural, spatial, and financial restrictions, which make up an argument already naturalized and accepted, one that should not be disputed. In this way, free discussion is moderated bilaterally, where those who do not have access to it accept that this
\end{abstract}

* Wydział Nauk Politycznych i Studiów Międzynarodowych Uniwersytetu Warszawskiego; (sara.burchert@gmail.com) iD https://orcid.org/0000-0001-5836-2141 
dostępu akceptują fakt, że nie powinni go mieć, często nawet nie analizując mechanizmów ujarzmiania, jakie stoją za kolejnymi procesami wykluczenia, ewentualnie - absorpcji w ramy głównego nurtu, odzierając z kolei jednostkę z ,mniejszościowego" charakteru, tożsamości, możliwości artykulacji własnych interesów.

Słowa kluczowe: demokracja liberalna, absorpcja, marginalizacja, pluralizm is the result of objective premises, often without even analyzing the mechanisms of subjugation behind subsequent exclusion processes, or possibly - absorption within the mainstream. These processes deprive an individual person of their "minority" character, their identity, and the possibility of articulating their own interests.

Keywords: liberal democracy, absorption, marginalization, pluralism

\section{Wprowadzenie}

Autorka artykułu odwołuje się do problemu pluralizmu, który stanowi nieodłączny dylemat w ramach rozważań nad demokracją liberalną. Kluczowe dla opracowania są kategorie absorpcji i marginalizacji, które z jednej strony stanowią zaprzeczenie idei demokracji liberalnej, z drugiej - są podstawą jej stabilnego funkcjonowania. W artykule zostają poruszone różne koncepcje pluralizmu (liberalno-agregatywne, deliberatywne, agonistyczne), choć największą uwagę skupiono na dwóch ostatnich, a więc na mechanizmach związanych z deliberacją oraz na agonistycznych interpretacjach demokracji. Mniejszości rozumiane są przede wszystkim na poziomie lokalnym, w ramach poszczególnych państw liberalno-demokratycznych, przyjmując kategorię mniejszości w ujęciu społeczno-kulturowym i przeciwstawiając ją nie ,większości”, a grupie dominującej. Jednocześnie za wystarczające dla zaistnienia marginalności przyjmuje się występowanie czynników obiektywnych, subiektywne poczucie mniejszościowości bowiem nie zawsze towarzyszy obiektywnym wyznacznikom, może być również wypierane bywa za pomocą rozmaitych mechanizmów w celu utrzymania rozproszenia, które utrudnia, a niekiedy uniemożliwia, wytworzenie podmiotowości i podjęcie działań.

\section{Pluralizm jako atrybut demokracji liberalnej}

Należy zauważyć, że pluralizm jest niezbędny w demokracji liberalnej i pisał o tym już John Stuart Mill, wskazując, że pluralizm i wolność głoszenia własnych poglądów są podstawą zdrowego społeczeństwa. Isaiah Berlin, odnosząc się do opinii Milla, twierdził, iż „silne poczucie wielostronności prawdy i nie- 
redukowalnej złożoności życia, które wyklucza już samą możliwość prostych rozwiązań oraz ideę jakiejś ostatecznej odpowiedzi na jakikolwiek konkretny problem" (Berlin, 2017, s. 292). Mill zakładał, że ignorowanie i zagłuszanie prawdy z pozycji kogoś, kto ma większy autorytet bądź też władzę, jest nierozważne i szkodliwe, gdyż może doprowadzić do stłumienia w istocie ważnych i słusznych problemów. W tym miejscu warto odwoływać się do wielu autorów, którzy zakładali, iż pluralizm jest cechą kluczową dla demokracji. Demokracja musi gromadzić szeroką bazę różnorodnych przekonań, które będą kształtowały wizję dobrego społeczeństwa. Julian Baggini pisze, że „Demokracja musi być połączona z pewnym rodzajem pluralizmu, by stała się środkiem do negocjacji między różnymi interesami i wizjami dobrego życia, a nie tylko sposobem kolektywnego decydowania, którą drogą pójść" (Baggini, 2015, s. 408). Podobnie uważa Robert T. Craig, twierdząc, że pluralizm, funkcjonowanie konkurencyjnych partii i instytucji, pluralistycznych mediów, jest podstawą demokracji liberalnej (Craig, 2018, s. 194). Craig wskazuje, że wbrew obiegowej opinii, jakoby pluralizm wiązał się z relatywizmem, to paradoksalnie jest on potwierdzeniem przeciwieństw między relatywizmem a monizmem. Zdaniem Craiga pluraliści nie uważają, że wszystko jest tak samo dobre, ale przyjmują pogląd, iż w różnych kulturach, różnych sytuacjach mogą istnieć funkcjonalne koncepcje dobrego życia, które będą z sobą niekompatybilne (Craig, 2018, s. 195).

Warto przytoczyć treściwą definicję pluralizmu, jaką zaproponował Michael Parenti. Wskazuje on, że pluralizm oznacza, że

„a) władza jest rozdzielona pomiędzy reprezentatywne części społeczeństwa,

b) w kształtowaniu polityki publicznej bierze udział znaczna liczba wzajemnie rywalizujących grup społecznych,

c) żadna $\mathrm{z}$ tych grup nie posiada trwałej dominacji ani nie jest zawsze przegrana oraz

d) podział korzyści jest mniej więcej sprawiedliwy, a z całą pewnością nie ma konsekwentnie eksploatacyjnego charakteru" (Parenti,1982, s. 400).

Danielle Raeijmaekers i Pieter Maeseele uważają, że można wyodrębnić trzy modele myślenia o pluralizmie: liberalno-agregacyjny, deliberatywny oraz agonistyczny. Zdaniem autorów w pierwszym z nich zakłada się, że należy rozpoznać najbardziej rozpowszechnione, silne preferencje i na ich podstawie zbudować powszechny konsens. W tej koncepcji kładzie się nacisk na reprezentację, która, posiadając specjalistyczną wiedzę, będzie mogła podejmować decyzje. W tym ujęciu uwidacznia się kwestia postrzegania relacji między mniejszością a większością w kategoriach głównie ilościowych. Model deliberatywny, zdaniem autorów, charakteryzuje przede wszystkim przywiązanie do racjonalnych praktyk komunikacyjnych, w których uwzględniane będzie szerokie spektrum uczestników. Spory takie, prowadzone przez obywateli, mają pozwolić na wypracowanie uzgodnień. W modelu agonistycznym krytykuje się ten sposób myślenia, gdyż próby przekroczenia ideologicznych przekonań są z natury skazane 
na niepowodzenie ze względu na heterogeniczność, jaką obserwować można w społeczeństwie. Badacze, którzy znajdują się w tej grupie, obawiają się, iż ustanawianie skali, na której charakteryzowane będą poglądy, w rozumieniu postideologicznym, w zgodzie z formami wcześniej ustanowionej racjonalności, spowodują jedynie, iż dominujące idee zostaną znaturalizowane (Raeijmaekers, Maeseele, 2015, s. 1044-1047).

Warto przybliżyć agonistyczne interpretacje pluralizmu. W Agonistyce Chantal Mouffe przekonuje, że pluralizm to nie jest zjawisko, które należy redukować czy też po prostu tolerować, a raczej coś, co powinno stanowić podstawę aksjologiczną funkcjonowania systemu. Celem nie powinna być redukcja konfrontacji, a raczej umożliwienie ich zaistnienia. Tworzenie rozmaitych tożsamości oraz dostarczanie ram pozwalających na wytworzenie się identyfikacji wydaje się bazą dla demokracji. W takiej wizji określone grupy nieustannie dążą do tego, by ich wartości uzyskały pozycję hegemoniczną, natomiast odbywa się to $\mathrm{w}$ nieustannej walce $\mathrm{z}$ przeciwnikiem (nie wrogiem), w której ramach nie można kwestionować tego, że inni również będą walczyć o swoje wartości. Warunkiem konsensu, który musi zaistnieć, zdaniem Mouffe zawsze jest niezgoda. Mechanizm taki nazywa ona „konsensem konfliktowym” (Mouffe, 2015, s. 21-23). Judy Brown, odwołując się do agonistycznych koncepcji, wskazuje, że władza w demokracji zawsze opiera się na następujących po sobie aktach włączania oraz wykluczania, dzięki którym mogą zaistnieć tożsamości społeczne i ramy identyfikacyjne. Wyznaczają one również granice. Jednocześnie autorka przytacza koncepcje, które wskazują na to, że grupy dominujące nie tylko zarządzają obowiązującymi interpretacjami rzeczywistości, ale też nie przyjmują do wiadomości, że ich punkt widzenia jest stanowiony jako jakaś perspektywa (Brown, 2009, s. 322).

Roszczenia do obiektywnej prawdy, jakie objawiają się w narracji hegemonicznej, w agonistycznym modelu demokracji miałyby podlegać demistyfikacji poprzez kontrhegemoniczne, ale też kooperacyjne propozycje grup podlegających marginalizacji (Brown, 2009, s. 334). Autorka umieszcza te koncepcje jako trzecią generację podejścia do pluralizmu, poststrukturalistyczną, w której podkreśla się brak trwałych tożsamości we współczesnym świecie. Tożsamości funkcjonują raczej jako kategorie nieustannie wytwarzane w codziennych interakcjach (Brown, 2017, s. 31-34). Należy jednak podkreślić, że wymaga to ustanowienia odpowiednich narzędzi i postaw w ramach politycznego porządku. Jednocześnie silne jest podkreślenie, że chodzi o wytworzenie jedności poprzez akceptację, a także wspieranie bądź podtrzymywanie heterogeniczności. Należy wskazać, że choć propozycje przełamania problemów liberalnej demokracji zostały znacznie poszerzone i uszczegółowione, wciąż należy uznawać, że przytoczone elementy pluralizmu, jakie wymienił Parenti, wydają się trafne.

Warte podkreślenia jest, że dla Mouffe granice pluralizmu wyznacza kwestia porządku szanującego zasady wolności i równości. Choć w tym przypadku 
z jednej strony Mouffe stawia bardzo rozległe granice (w kontekście wolności słowa), z drugiej zaś problemy budzi ich interpretacja w kontekście formowania partii politycznych (klasyfikacja wroga). W tym pierwszym przypadku jedynie wypowiedzi, które stanowią formę nawoływania do przemocy wobec określonej grupy/jednostki, mogą podlegać represji (Dreyer, Sonnischen, 2014, s. 269). Pytanie, jakie naturalnie pojawia się w odniesieniu do porządków, których funkcjonowanie jest oparte na praktykach dyskursywnych, dotyczy jednak tego, w jakim stopniu możliwe jest wprowadzenie pluralizmu hegemonii. Należy przy tym jednak podkreślić, że sam fakt szerokiego zainteresowania problemem pluralizmu w demokracji oraz jego granic stanowi głos na rzecz tego, że demokracja nieustannie mierzy się z jego definicją, mechanizmami funkcjonowania oraz uprawomocnieniem.

Należy przy tym zauważyć, że choć korzenie demokracji liberalnej wiązały się z postulatem włączenia kolejnych grup społecznych $\mathrm{w}$ ramy partycypacji obywatelskiej, a sama demokracja charakteryzowana bywa przez pryzmat jej otwartości, to współcześnie znani są autorzy wskazujący, iż demokracja nie może funkcjonować bez zjawiska wykluczenia (Beckman, 2014, s. 396). Jest to ściśle związane z tym, iż każde włączenie pociąga za sobą wykluczenie osób, które nie spełniają warunków włączenia. Demokracja liberalna jest wierna procedurom, prawu, rozwiązaniom instytucjonalnym (Szahaj, 2019, s. 40), a - jak wskazuje Zygmunt Bauman - stan wykluczenia wiąże się z samozawieszeniem, z faktem, że nie funkcjonują normy prawne w odniesieniu do określonej grupy czy jednostki (Bauman, 2004, s. 53), co nie jest obce porządkom demokratycznym.

Nieco inne podejście w tym aspekcie ma Judith Butler, która uznaje, że włączenie do porządku prawnego norm odpowiadających wykluczonym może jedynie utwierdzać funkcjonowanie hegemonicznej uniwersalności. Butler wskazuje, że „roszczenie do objęcia »prawem《 do małżeństwa osób nieheteroseksualnych [...] pogłębia przepaść między prawowitymi i nieprawowitymi formami seksualnej wymiany" (Butler, 2014, s. 206). Tym samym sposobem zanegowania dominującej interpretacji byłoby raczej pozbawienie możliwości ich oddziaływania i zakwestionowanie ich mocy. Wydaje się jednak, że zarówno forma samozawieszenia, jak i interpretacja zaproponowana przez Butler, są różnymi wariantami interpretacji tego samego zjawiska, problem bowiem tworzenia nowego prawa, które ma na celu włączenie kolejnych grup, jednocześnie będzie pozostawiał poza marginesem inne, stąd też zasadna staje się propozycja Butler, możliwa do przeprowadzenia w podawanym przez autorkę aspekcie. Słuszne wydaje się jednak postawienie pytania o to, czy jest ona możliwa w każdym z innych aspektów, czy jednak nie czyni z wykluczenia (formalnego i nieformalnego) podstawy swojego funkcjonowania, jako że demokracje liberalne budują swoją tożsamość na odróżnieniu od ,niedemokratycznego" zewnętrza lub równolegle na włączaniu go. W tym aspekcie warte przytoczenia wydają się ustalenia, jakie proponuje 
Ian Sharpiro. Zdaniem autora, który swoje rozważania opiera na licznych badaniach, to właśnie formalnie egalitarne systemy neutralizują możliwości oporu i kontestacji, nie istnieje bowiem wyraźna granica między grupą dominującą a podporządkowaną, wykluczoną, zmarginalizowaną (Sharpiro, 2006, s. 162-164).

Judy Brown twierdzi, że istnienie demokracji zakłada granicę, która oddziela od niej sferę niedemokratyczną stanowiącą o jej samookreśleniu. Według Brown współcześnie takim elementem jest „islamizm”, który obnaża antyuniwersalistyczne podejście leżące u podstaw demokracji liberalnej. Jest to jedynie zobrazowanie pewnego mechanizmu, trwale wbudowanego w kształtowanie tożsamości. W tym kontekście Michael Saward przytacza, iż pojawiają się głosy o wbudowanych w islam demokratycznych zasadach, a także, że przywoływana wrogość wobec demokracji bywa po prostu wrogością wobec Zachodu (Saward, 2008, s. 134-136). Alain Badiou posuwa się do twierdzenia, że krytyka jakiegokolwiek mechanizmu winna być motywowana działaniem na rzecz demokracji. Zdaniem autora tak rozumiana demokracja to konserwatywna oligarchia, przeświadczona o wyłączności swojego ,świata”, wsparta na niedemokratycznym tle i wykluczeniu, które zostaje ostatecznie znaturalizowane (Badiou, 2012, s. 15-17). Współczesną demokrację przedstawicielską jako oligarchiczną opisywał także Jacques Rancière, który postrzega państwa te (współczesne demokratyczne) jako oligarchiczne, przyznające demokracji pewną ilość miejsca do realizacji namiętności, miejsca, które zostało przez nią wywalczone (Rancière, 2008, s. 88-92). Ta neutralizacja nazbyt intensywnych, według przyjmowanej normy, namiętności w demokracjach coraz częściej stanowi przedmiot rozważań. Dwoistość procesu wyborczego dostrzega Iwan Krastew, wskazując, że z jednej strony demokracja zapewnia wymienialność elit władzy, którą Rancière nazwałby raczej pozorną, co chroni obywateli przed rozbudowanym aparatem represji, z drugiej natomiast skupienie na mechanizmach instytucjonalnych służy również ignorowaniu namiętności i prowadzi do pacyfikacji ekspresji obywateli (Krastew, 2015, s. 45).

\section{Mniejszość, marginalizacja, absorpcja - analiza pojęciowa}

Przyglądając się pojęciu mniejszości, należy zauważyć, iż rozpatrywana ona będzie w kategoriach społeczno-kulturowych. Sama liczebność nie jest warunkiem wystarczającym zaistnienia mniejszości, co potwierdza wiele analiz i sformułowanych definicji. Zwraca się również uwagę na fakt, że obserwować można zbiorowości liczebnie większe, które doznają znaczącego upośledzenia. Należy w tym miejscu podkreślić również, że w takim wypadku mniejszości nie bę- 
dziemy przeciwstawiać większości, a grupie dominującej. Podstawową cechą, jaką wskazuje się w rozmaitych definicjach, jest dyskryminacja. Jak podkreśla Hanna Bojar, „Grupa zaliczana do mniejszości może stanowić liczebną większość, jest jednak mniejszością ze względu na społeczne, polityczne i ekonomiczne podporządkowanie grupie dominującej" (Bojar, 2000, s. 18).

Należy również wskazać, że konieczne jest przyjęcie perspektywy, w stosunku do której mniejszość będziemy kategoryzować, a która wyznaczać będzie pewną społeczną całość. W przypadku rozważania antynomii demokracji warto posłużyć się rozumieniem lokalnym i pozycją mniejszości w ramach państwa liberalno-demokratycznego. Należy też zwrócić uwagę na to, iż w definiowaniu mniejszości przyjmuje się fakt istnienia bądź obiektywnych, bądź subiektywnych przesłanek określenia zbiorowości jako mniejszościowej. W wielu koncepcjach zakłada się współistnienie obiektywnych oraz subiektywnych czynników.

W kontekście systemu demokratycznego, którego istotą jest uczestnictwo jednostek w życiu politycznym, warto przyjąć założenie, które przyjmował również Michael Smitch, iż wystarczające są czynniki obiektywne, które wskazują na upośledzenie grupy społecznej, by uznać ją za kategorię mniejszościową (Bojar, 2000, s. 51). Stopień subiektywnej interpretacji swojej pozycji w strukturze społeczno-politycznej, niezmiernie istotny z punktu widzenia jego konsekwencji, mogących wyrażać się w organizowaniu grupy oraz uzyskiwaniu podmiotowości politycznej, w kontekście podjętego problemu wydaje się drugorzędny, procesy marginalizacji bowiem przebiegają często w sprzężeniu z izolacją i alienacją, z kolei niski stopień świadomości sprzyjać będzie procesom absorpcji mniejszości.

Kolejnym istotnym czynnikiem, który uzasadnia tak poczynione założenie, jest fakt, że model, w którym zakłada się kluczową wagę czynników subiektywnych, wskazuje na ich funkcjonalność w kontekście organizowania się w grupy, które następnie mogą wywierać wpływ na życie polityczne. W tym miejscu należy poczynić również zastrzeżenie - absorpcja rozumiana jest, zgodnie z definicją słownikową, jako wchłanianie. Istotne jest podkreślenie, iż występuje znacząca różnica między procesem absorpcji a szeroko rozpowszechnionym w terminologii badań nad mniejszościami pojęciem inkorporacji, które oznacza włączenie, a więc nie sugeruje w konsekwencji całkowitej asymilacji danej mniejszości. Inkorporacja polega na tym, że element „włączony” może mimo wszystko zachować swoistą odrębność, cechować się szczególnymi modułami tożsamości $\mathrm{w}$ ramach porządku. Absorpcja $\mathrm{z}$ kolei polega na zniwelowaniu, zwłaszcza na poziomie subiektywnej refleksji, wszelkich różnic, co, jak zostało wskazane, utrudnia uzyskanie podmiotowości.

Należy zwrócić uwagę na to, że w odniesieniu do całości społecznej istnienie grup wykluczonych lub zmarginalizowanych stanowi potwierdzenie roli i pozycji grup dominujących, które bardzo często świadomie wyodrębniają grupę odrzucenia, tworząc o niej odpowiednie wyobrażenie. Mogą wykorzysty- 
wać do tego funkcjonujące w społeczeństwie uprzedzenia i stereotypy, kreując wrażenie, iż wykluczona zbiorowość jest przeciwstawna wobec definiowanej większości. Jednocześnie w takiej sytuacji grupa ta nie posiada żadnych funkcji w odniesieniu do tych, którzy w sposób arbitralny zostali do niej włączeni, nieuniknione więc wydaje się odcięcie od wytworzonej narracji ze względu na pozycję społeczną środowisk, które są zainteresowane jej uprawomocnieniem i podtrzymaniem (Erenc, 2013, s. 15).

Badacze wskazują, że z pojęciami marginalności, marginalizacji i wykluczenia wiążą się takie terminy, jak bezbronność, ubóstwo, nierówności, deprywacja, odłaczenie, niepewność, stygmatyzacja, dyskwalifikacja, segregacja czy też różnice społeczne i wiele innych. Tym, co należy zastrzec, jest fakt, że deprywacja może mieć dwa rodzaje źródeł. $Z$ jednej strony można mówić o źródłach zewnętrznych, związanych z działaniami przyrody, aparatu państwowego, grup społecznych czy jednostek, z drugiej - można też samemu pozbawić się praw, zarówno poprzez działanie, jak i zaniechanie działania (Kowalak, 1998, s. 16). Tadeusz Kowalak wskazuje, że poziom marginalności określa się za pomocą stwierdzenia, w jakim stopniu konkretna jednostka bądź grupa jest pozbawiona uprawnień, władzy, wyboru, dostępu do wypoczynku, dóbr materialnych czy kulturowych, w jakim stopniu jest przymuszana do podjęcia określonych działań, napiętnowana bądź dyskryminowana, a także jaki jest stopień jej bezradności. Należy przy tym zaznaczyć, iż marginalność stanowi pojęcie, które zawsze odnosi się do porównania z inną grupą społeczną w konkretnej kategorii, w związku z tym jest pojęciem relatywnym (Kowalak, 1998, s. 27).

Kiedy mowa o absorpcji, należy zwrócić szczególną uwagę na koncepcję hegemonii. Warto zauważyć, że heterogeniczność sprawia, iż granice społeczne zostają ujawnione, w związku z czym hegemonia ma szanse znaturalizowania tego, co wcześniej należało do heterogenicznych porządków, uwspólniając ich znaczenie z rozumieniem dominującym. W ten sposób różnorodność odtwarza i podtrzymuje dominujące formy tożsamości i stosunków społecznych (Bloom, Dallyn, 2011, s. 66). Autorzy nazywają proces naturalizacji swoistym zarządzaniem pluralizmem. Wskazują, że w liberalnej demokracji mamy do czynienia z zaspokojeniem potrzeby „słyszenia opinii innych”, które jednak stanowi jedynie mechanizm maskowania monizmu. Te „napięcia regulacyjne” zapewniają ciągłość trwania systemu (Bloom, Dallyn, 2011, s. 74). Jest to niejako potwierdzenie tezy Antonio Gramsciego, który uważał, iż nie można rozpatrywać hegemonii jako istniejącej w próżni i ignorującej interesy grup podporządkowanych. Wskazywał, że ofiary i kompromisy są konieczne do jej podtrzymania, natomiast nigdy nie dotyczą kwestii zasadniczych (Gramsci, 1961, s. 531).

Rozważania nad absorpcją warto uzupełnić podkreśleniem pojęcia asymilacji. Absorbowanie w dużej mierze wiąże się z asymilacją danej grupy. W interpretacji Tadeusza Palecznego asymilacja stanowi złożony proces, w którego ramach „,dochodzi do częściowego albo całościowego zmieszania bądź zlania 
się elementów składowych co najmniej dwóch, lub większej liczby grup kulturowych" (Paleczny, 2017, s. 63). W tym procesie autor wskazuje na elementy nakładania się na siebie oraz scalania, jak też uniwersalizacji tożsamości grupowej. Autor podkreśla, że proces ten wieńczy zazwyczaj powstanie nowego systemu kulturowego, w którym zarówno grupy, jak i jednostki do nich należące, przyjmują wspólne kody komunikacyjne, normy i systemy wartości. Zdaniem Palecznego proces ten nie prowadzi do homogenizacji, a raczej do wytworzenia transkulturowego środowiska politycznego, prawnego, społecznego, w którego ramach powstają nowe kultury (Paleczny, 2017, s. 64). W myśli Palecznego wyłania się również pozytywny obraz procesów asymilacji, która, jeśli przyjmie się odpowiednie wzory wykorzystania i wcielania w życie, może występować w postaci wielokierunkowej, tworzącej wspólny grunt, a jednocześnie nie totalnej, która mogłaby całkowicie unicestwić dawne tożsamości grupowe heterogenicznego społeczeństwa. Wydaje się, że podejmując perspektywę Palecznego o stopniowalności i jakościowych różnicach w akceptowanych rozwiązaniach, absorpcję można ujmować jako proces, którego pożądanym efektem jest narzucenie grupie przyjmowanej zespołu norm odpowiadającego społeczeństwu przyjmującemu, grupie dominującej. W tym sensie można odnotowywać zagrożenie dla pluralizmu, choć, na co wyraźnie wskazuje Paleczny, nie zawsze asymilacja sama $\mathrm{w}$ sobie jest $\mathrm{z}$ różnorodnością i pluralizmem sprzeczna, może ona nawet sprzyjać pozostawaniu silnych więzi kulturowych, etnicznych czy religijnych, a także tworzeniu nowych interpretacji norm, niekoniecznie zgodnych jedynie $\mathrm{z}$ systemem aksjonormatywnym grupy przyjmującej (Paleczny, 2017, s. 68).

Kategorie mniejszości oraz większości są również przedmiotem zainteresowania w psychologii. Warto wskazać, że według prowadzonych badań doświadczenie bycia $\mathrm{w}$ grupie mniejszościowej, rozumianej przez pryzmat ilościowy, wiąże się z większym doświadczaniem negatywnych uczuć. Henricus Lücken i Joannes Simon wskazują, że jest to charakterystyczne szczególnie dla państw Zachodu. Mają przy tym na myśli kraje demokratyczne, w których kluczowe znaczenie ma zasada większości. Często podkreśla się, że grupy, które stanowią mniejszość w danym obszarze, charakteryzują się silniejszą identyfikacją kolektywną, bardziej ukształtowaną tożsamością. Badania autorów wykazały jednak, że choć mniejszość wyrażająca się jedynie w liczebności sama w sobie jest w stanie wywoływać negatywne doświadczenia emocjonalne, to różnica w sile grupy powodowała mocniejsze reakcje na poziomie zarówno emocjonalnym, jak i poznawczym. Wiązała się również z wyższą wrażliwością na utratę władzy. Ten rodzaj relacji mniejszość - większość przyczyniał się również do faktu, że członkowie grupy mniejszościowej wykazywali się wyższym poziomem niepewności. Należy zwrócić uwagę na to, że członkowie grup, które stanowią mniejszość, często znajdują się w sytuacji konfliktu wewnętrznego, ponadto mogą mieć trudność w pozytywnym postrzeganiu własnej przyna- 
leżności do grupy. Co bardzo istotne, badacze wskazują, że z fenomenologicznego punktu widzenia osoby takie mogą utracić doświadczanie istnienia jako czegoś naturalnego. W tym kontekście muszą nieustannie uświadamiać i tłumaczyć, sobie oraz otoczeniu, własną egzystencję (Lücken, Simon, 2005, s. 409-413).

Co ciekawe, element afektu podnoszony jest często w rozważaniach o mniejszościach, czy to w znaczeniu tylko ilościowym, czy też w związku ze statusem i władzą konkretnej grupy. Władzę przedstawia się również jako społeczną modulację afektu, wykorzystywanie go i przekształcanie jego znaczenia. Nicholas Thoburn wskazuje na to, że grupy poddane takiej aktywacji afektywnej mogą odczuwać coś na kształt konfliktu wewnętrznego, w którym ich emocje przekształcane są $\mathrm{w}$ mechanizmy systemu. Thoburn egzemplifikuje to kwestią elastyczności pracy, która lęk zamienia w wymaganie operacyjne, wpisując go w codzienny porządek (Thoburn, 2007, s. 86).

\section{Marginalizacja i absorpcja mniejszości w dyskursie publicznym}

Markus Holdo oraz Lizzie Öhrn Sagrelius wyróżnili pięć mechanizmów marginalizacji, jakie występują w deliberacyjnym modelu demokracji, rozumianym przede wszystkim jako zapewnienie wszystkim obywatelom takich samych szans, pozwalających im angażować się w debaty publiczne dotyczące społecznych problemów. Wskazują, że istnieje wiele mechanizmów, które utrudniają wprowadzenie w życie ideałów takiej demokracji, a których wspólnym mianownikiem jest wykluczenie bądź też marginalizacja spowodowana chociażby sposobem, w jaki ludzie rozmawiają, różnicami w wykształceniu czy pozyskiwaniu informacji, ułomnym tworzeniem warunków dyskusji czy też nierównościami w dostępie do zasobów. Zdaniem autorów, na pięć głównych mechanizmów, które są przyczynami marginalizacji, składają się:

- prowadzenie i utrzymywanie dyskusji w ramach dominującej/zastanej narracji - wówczas nieprzystające poglądy zostają marginalizowane i ignorowane;

- przedstawianie przez liderów opinii publicznej określonej perspektywy jako „lokalnej”, wyrażanej przez jakiegoś przedstawiciela wybranego odgórnie skutkuje to podwójną marginalizacją; wynika ona z tego, że dane środowisko jest jednorodne i wówczas pewne osoby są podwójnie marginalizowane - z jednej strony są członkami takiej grupy, z drugiej z kolei są podporządkowane również w jej ramach;

- dominujące lub też wpływowe podmioty na scenie politycznej mogą narzucać odpowiadającą sobie narracje, a także warunki, na jakich odbywać się 
będzie debata i dostęp do niej - to zmusza uczestników do podporządkowania się i zdystansowania wobec własnych interesów czy też poglądów;

- omijanie przez uczestników debaty sedna sprawy, które przedstawia mówiący, skupiając się raczej na różnicach, często związanych z pochodzeniem, przynależnością klasową, wykształceniem, płcią, wyglądem zachowaniem czy sposobem mówienia;

- ustalanie przez dominujących aktorów takiego programu debaty, by poruszane kwestie nie były „zbyt złożone lub delikatne” dla rozmówców - wówczas są one tematem dyskusji, jednak jedynie wśród decydujących podmiotów - pozostali zostają z góry z dyskusji wykluczeni (Holdo, Öhrn Sagrelius, 2019, s. 5-6).

Analizując przedstawione elementy, można dostrzec, że część z nich skutecznie może prowadzić do absorpcji określonej mniejszości. Zarówno prowadzenie debaty $\mathrm{w}$ ramach dominującej narracji, jak i zakładanie, że dane środowisko jest jednorodne i przedstawianie go w takim świetle, może skutkować absorpcją określonych mniejszości. W tym drugim przypadku absorpcja może dotyczyć przede wszystkim środowiska, jeśli jednak będziemy w sytuacji, w której te dwa elementy się zazębiają, wówczas całe środowisko może zostać włączone w ramy narracji dominujących aktorów. Ponadto, jak wskazuje Gramsci, w ramach każdej grupy obserwujemy podział na rządzących i rządzonych. Założenie, iż taki podział jest ostateczny, skutkuje popełnianiem istotnych błędów. Gramsci wskazuje, ,że skoro raz przyjęto zasadę wspólnoty interesów jednej grupy, posłuszeństwo musi następować automatycznie, bez potrzeby wskazywanie jego zasadności i konieczności, bez prawa do dyskusji" (Gramsci, 1961, s. 511). Jest to istotny problem w kontekście podstawowej zasady nowoczesnej demokracji, w ramach której zderzenia opinii i artykulacja interesów powinny służyć ustaleniu strategii jak najpełniejszej realizacji dobra wspólnego.

Holdo oraz Öhrn Sagrelius zwracają uwagę na jeszcze inny problem - wskazują, że w przypadku wystąpienia sytuacji, w której ścierają się z sobą dwie dominujące narracje, przeciwstawienie się jednej z nich skutkuje automatycznie przyporządkowaniem danej grupy czy też jednostki do drugiej narracji. Dostrzega się też, że demokracje liberalne charakteryzuje malejący poziom uczestnictwa, co w konsekwencji powoduje, iż debatę publiczną prowadzą jedynie profesjonalne i elitarne kręgi, a jej charakter merytoryczny i sposób prowadzenia stają się niezrozumiałe. Ponadto minimalizuje się możliwości mobilizacji środowisk mniej uprzywilejowanych. Stephen Turner posługiwał się pojęciem dyskursywnej asymetrii, w której eksperci dysponują możliwością wpływania zarówno na siebie nawzajem, jak i na nieuprzywilejowanych, podczas gdy ta druga grupa nie posiada takiej możliwości. Należy przy tym zauważyć, że choć autor wskazuje, że w takim wypadku pojęcie dialogu staje się iluzją, to demaskuje on również próby instytucjonalnych rozwiązań, mających racjona- 
lizować debatę publiczną. W tym celu powoływać można organizacje i komitety profesjonalizujące komunikację $\mathrm{z}$ obywatelami, jednocześnie jednak ich apolityczność wciąż jest jedynie pozorem (Turner, 2003, s. 5-64). Phil Parvin zwraca uwagę na fakt, że niski poziom partycypacji obywateli z nizin społecznych w dużej mierze uwarunkowany jest brakiem polityki edukacyjnej, a także możliwości aktywizowania się w ruchach stowarzyszeniowych. Brak udziału w stowarzyszeniach lub innych formach zaangażowania, wymagających wykształcenia więzi społecznych, skutkuje uniemożliwieniem świadomego udziału w debacie politycznej (Parvin, 2018, s. 36).

W przypadku narastania tych tendencji możemy obserwować to, co Mirosław Karwat określa „elitarystyczną redukcją demokracji”. Jest to wzorzec demoelitarny, w którego ramach formalnie uznawana jest suwerenność ludu czy postulat równości praw, w praktyce natomiast mechanizmy kontroli społecznej ograniczone są do rotacji w ramach elit (Karwat, 2016, s. 21-23). Karwat wskazuje, że ,jest to wybiórcze celebrowanie demokracji: cały wysiłek włożony jest nie tyle w to, by wpoić obywatelom potrzebę aktywności, zainteresowanie polityką, niezbędną wiedzę i informację, tudzież postawę samodzielności, krytycyzmu, refleksyjności, aspiracje do kontroli i do własnej aktywności w nacisku społecznym, ile w to, by obywatele kiedy trzeba głosowali »jak trzeba«" (Karwat, 2016, s. 22). Na potwierdzenie tego faktu można wskazać chociażby rozważania Andrzeja Szahaja dotyczące pozornego i rytualnego charakteru konfliktu, jaki występuje pomiędzy poszczególnymi środowiskami politycznymi, którym towarzyszy poczucie wspólnoty interesów w ramach elit (Szahaj, 2014, s. 74). Badacz twierdzi, że arogancja elit politycznych sprawiła, iż rosnące nierówności doprowadziły do wyłonienia się rzesz ludzi „zbędnych” (Szahaj, 2014, s. 77).

Warte wzięcia pod uwagę wydaje się to, co współcześnie jest problemem innej grupy społecznej, jaką tworzą młodzi dorośli, którzy w starzejących się społeczeństwach państw liberalnych demokracji zaczynają stanowić grupę mniejszościową. Craig Berry zwraca uwagę na fakt, że w historii demokracja funkcjonowała na zasadzie piramidy, gdzie młodsze pokolenia stanowiły najliczniejszą kohortę. Współcześnie, niezależnie od rozmiaru ich grupy, nie stanowią one większości, podczas gdy podejmowane aktualnie decyzje polityczne będą miały kumulatywny wpływ na ich funkcjonowanie społeczno-ekonomiczne (Berry, 2014, s. 720). Powszechny w części państw stereotyp, iż polityka przeznaczona jest dla osób starszych, w domyśle - bardziej kompetentnych, zatem poczucie bezsilności i braku odpowiadającej młodym oferty może również stanowić czynnik zniechęcający do udziału w demokratycznych wyborach. Młodość, kojarzona z niekompetencją, może być również powodem do dyskredytacji w kręgach politycznych. Guy Standing zauważa, że emeryci stanowili jedną $\mathrm{z}$ chronionych grup podczas wprowadzania polityki zaciskania pasa, za czym, zdaniem autora, stała utylitarna motywacja, gdyż starszych cechuje ich 
znacząco wyższa skłonność do głosowania ${ }^{1}$. W stosunku do młodego pokolenia grupy dominujące mogą zastosować bardzo podobne schematy, które stosowane są w stosunku do innych mniejszości, uwypuklając formalne włączenie i marginalizując ich doświadczenie mniejszościowości. Standing twierdzi, iż „Nowoczesny utylitaryzm ma kilka przebrań, ale każde z nich zdaje się uzasadniać działania na rzecz większości i przeciw mniejszości, do tego stopnia, że stara się racjonalnie argumentować za pozaprawnymi formami kar zbiorowych" (Standing, 2015, s. 111).

\section{Wnioski - marginalizacja jako wyparcie, absorpcja jako przeistoczenie walczących pluralizmów}

Marginalizacja może opierać się na co najmniej dwóch założeniach. Pierwszym z nich jest świadome wskazywanie grupy mniejszościowej (czy w sensie ilościowym, czy społeczno-kulturowym) po to, by grupa dominująca miała możliwość ukonstytuowania własnej tożsamości negatywnej, a nawet uruchomienia w swoich ramach mechanizmów obronnych, które umacniać będą się we wspólnocie w odniesieniu do prostej zasady - „musimy trzymać się razem”. Marginalizacja jednak, czy to grup społecznych, czy też konkretnych problemów, może stanowić mechanizm wyparcia. Pojawienie się nowych, niedookreślonych zjawisk, grup, podmiotów, mogących być przyczyną działań, których skutki pozostają dla systemu niedookreślone, a potencjalnie mogą pozostawać niebezpieczne, rodzi potrzebę wyciszenia lęku, który pojawia się w obliczu nieznanego.

Gdy Erich Fromm poddaje analizie „człowieka organizacji”, który odczuwa bezsens własnych działań, to potencjalne uświadomienie sobie tego traktuje jako zagrażające porządkowi społecznemu (Fromm, 2018, s. 132). Fromm wskazuje też, że konieczność wyparcia jest „tym większa w im większym stopniu społeczeństwo nie jest reprezentacyjne dla swych członków" (Fromm, 2018, s. 133). Dalej potwierdza tę tezę, akcentując, że społeczeństwa, które w założeniu mają troszczyć się o wszystkich, są tak naprawdę oszustwem, które jednak musi utrzymywać większość w przeświadczeniu, że jest inaczej. Należy przy tym podkreślić, że mowa tu o większości. Gdy więc w obszernej większości, połączonej na podstawie niedookreślonej uniwersalności wykrystalizuje się poczucie mniejszościowości, którego efektem mogą być działania niebezpieczne

${ }^{1}$ Autor powołuje się na przykład polityki Camerona w Wielkiej Brytanii, zaznaczając, że istniało wówczas wyraźne prawdopodobieństwo, że zagłosują na konserwatystów za: Standing, 2015, s. 124. 
dla trwałości demokracji, wówczas marginalizacja odzwierciedla wyparcie tego, iż demokracja w swej istocie nie jest pełną reprezentacją, ani też nie jest w stanie realizować włączania, bez jednoczesnego wykluczania. W tym kontekście demokracja „obawia się” pluralizmów, gdy bowiem przybierają one na sile, gdy nie można określić ich już mianem partykularyzmów, co samo w sobie stanowi mechanizm wykluczający, wówczas w pełni uświadomione może zostać „oszustwo", na jakim demokracja się opiera. W tym kontekście obawa przed tym, iż realne pluralizmy uczynią zarządzanie nimi niemożliwe, sprawia, że zwolennicy demokracji liberalnej usiłują wyprzeć istniejące napięcia, oferując niejednokrotnie w zamian pozorne pluralizmy, których uzewnętrznienie nie zachwieje status quo.

Podpierając się założeniami, w których na pierwszy plan wysuwa się mnogość pluralizmów, mogących uczestniczyć w walce o hegemonię bądź też o zaanektowanie luk, które w tejże zawsze się znajdują, mając jednocześnie w pamięci, że demokracji nie trzeba charakteryzować poprzez rządy ludu, a można spojrzeć na nią, jak na konserwatywną oligarchię, możemy stwierdzić, że absorpcja stanowi mechanizm rozbrajający pluralizmy, zacierający granicę bądź też uniemożliwiający wytyczenie jej, a więc dezaktywuje te namiętności, które w jej ramach mogły doczekać się wypełnienia i wyeksponowania, jako emanacja prawdziwej demokracji w rozumieniu Rancière'a.

Uspokojenie tychże namiętności, które w niektórych ujęciach postrzegane są jako zbyt jaskrawe, niebezpieczne dla zastanego porządku, staje się ważnym ogniwem, gdy zwróci się uwagę na psychologiczne czynniki związane z przynależnością grupową. Shapiro przywoływał istotną kwestię dotyczącą przepuszczalności grupy. Podstawowym elementem, który sprawia, że ludzie opowiadają się bardziej za indywidualnymi wysiłkami niż zbiorowym działaniem, jest fakt realnego istnienia możliwości dostania się do grupy aspiracyjnej. Demokracja absorbując kolejne przestrzenie żywiołowości, które niejednokrotnie pozostawały na obrzeżach i mogły być traktowane jako potencjalnie zagrażające w tym czy innym zakresie żywotnym interesom tych, którzy odpowiadali za stworzenie reguł gry, wprowadza nową regułę, dającą szanse na pełne włączenie już nie jako zbiorowości, ale jako indywiduum. Absorpcja jednocześnie nie oznacza wzmocnienia głosu tych, którzy wcześniej nie byli słyszalni, skutkiem czego zaciera granicę, jednocześnie nie dostarczając narzędzi pozwalających na pełne uczestnictwo w systemie.

Należy przy tym podkreślić, że paradoks pluralizmu dostrzec można i z perspektywy samej demokracji liberalnej - co stanowiło podstawę artykułu, i jako jej wewnętrzną sprzeczność, w ramach której obserwujemy, iż, choć ma on w założeniu stanowić źródło różnorodności i wielowymiarowości zarówno życia społecznego, jak i politycznej aktywności, w istocie sprzyja uniformizacji. Procesy absorpcji i marginalizacji ułatwiają rozmywanie się tożsamości i granic, co w konsekwencji prowadzi do ujednolicenia norm, a także obrazu świata. 


\section{Bibliografia}

Badiou, A. (2012). Demokracja jako emblemat. W: G. Agamben [et al.], Co dalej $z$ demokracja. Warszawa: Wydawnictwo Książka i Prasa

Baggini, J. (2015). The Populist Threat to Pluralism. Philosophy and Social Criticism 4 (4-5).

Bauman, Z. (2004). Życie na przemiat. Kraków: Wydawnictwo Literackie.

Beckman, L. (2014). Democracy and the Right to Exclusion. Res Publica 20.

Berlin, I. (2017). Wolność. Przeł. B. Baran. Warszawa: Wydawnictwo „Aletheia”.

Berry, C. (2014). Young People and the Ageing Electorate: Breaking the Unwritten Rule of Representative Democracy. Parliamentary Affairs 67.

Bloom, P., Dallyn, S. (2011). The Paradox of Order: Reimagining Ideological Domination. Journal of Political Ideologies 16 (1).

Bojar, H. (2000). Mniejszości społeczne w państwie i społeczeństwie III Rzeczpospolitej Polskiej. Wrocław: Wydawnictwo „Funna”.

Brown, J. (2009). Democracy, Sustainability and Dialogic Accounting Technologies: Taking Pluralism Seriously. Critical Perspectives on Accounting 20.

Brown, J. (2017). Democratizing Accounting: Reflections on the Politics of "Old" and "New" Pluralisms. Critical Perspectives on Accounting 43.

Butler, J. (2014). Rywalizujące uniwersalności. W: J. Butler, E. Laclau, S. Žižek, Przygodność, hegemonia, uniwersalność: współczesne debaty na lewicy. Przeł. A. Czarnacka, M. Kropiwnicki, S. Królak. Warszawa: Wydawnictwo Krytyki Politycznej

Craig, R.T. (2018). Reframing the Paradox of Pluralism as a Communication Problem. Javanost: The Public 25.

Dreyer, J.A. (2014). Sonnischen A., Radical Democracy, Agonism and the Limits of Pluralism: An Interview with Chantal Mouffe. Distinktion: Scandinavian Journal of Social Theory 15(3).

Erenc, J. (2013). Teoria grupy społecznej a mechanizmy wykluczenia. W: A. Kłonkowska, M. Szulc (red.), Społecznie wykluczeni. Niewygodni, nienormatywni, nieprzystosowani, nieadekwatni. Gdańsk: Wydawnictwo Uniwersytetu Gdańskiego.

Fromm, E. (2018). Zerwać okowy iluzji. Moje spotkania z myśla Freuda i Marksa. Kraków: Wydawnictwo Etiuda.

Gramsci, A. (1961). Nowoczesny Książę. W: Idem, Pisma wybrane. Przeł. B. Sieroszewska. T. 1. Warszawa: Wydawnictwo Książka i Wiedza.

Holdo, M., Öhrn Sagrelius L. (2019). Why Inequalities Persist in Public Deliberation: Five Mechanisms of Marginalization. Political Studies $1-19$.

Karwat, M. (2016). Pseudodemokratyczne wzorce polityki. W: M. Tobiasz (red.), Antynomie i paradoksy współczesnej demokracji. Warszawa: Dom Wydawniczy „Elipsa”.

Kowalak, T. (1998). Marginalność i marginalizacja społeczna. Warszawa: Dom Wydawniczy „Elipsa”.

Krastew, I. (2015). Demokracja: przepraszamy za usterki. Warszawa: Wydawnictwo Krytyki Politycznej. 
Lücken, M., Simon, B. (2005). Cognitive and Affective Experiences of Minority and Majority Members: The Role of Group Size, Status and Power. Journal of Experimental Social Psychology 41.

Mouffe, Ch. (2015). Agonistyka. Polityczne myślenie o świecie. Warszawa: Wydawnictwo Krytyki Politycznej.

Paleczny, T. (2017). Procesy asymilacji, transkulturacji i uniwersalizacji kulturowej. Przegląd problematyki. Krakowskie Studia Międzynarodowe 14(3).

Parenti, M. (1982). Demokracja dla nielicznych. Przeł. E. Woydyłło. Warszawa: Wydawnictwo Książka i Wiedza.

Parvin, P. (2018). Democracy Without Participation: A New Politics for a Disengaged Era. Res Publica 24.

Raeijmaekers, D., Maeseele, P., (2015): Media, Pluralism and Democracy: What's in a Name? Media, Culture \& Society, 37(7).

Rancière, J. (2008). Nienawiść do demokracji. Przeł. M. Kropiwnicki. Przekł. aneksu A. Czarnacka. Warszawa: Instytut Wydawniczy Książka i Prasa.

Saward, M. (2008). Demokracja. Przeł. A. Burek. Warszawa: Wydawnictwo Sic!

Sharpiro, I. (2006). Stan teorii demokracji. Przeł. I. Kisilowska. Warszawa: Wydawnictwo Naukowe PWN.

Standing, G. (2015). Karta prekariatu. Przeł. P. Juskowiak, P. Kaczmarski, M. Szlinde. Warszawa: Wydawnictwo Naukowe PWN.

Szahaj, A. (2019). Demokracja liberalna na glinianych nogach. W: Idem. Kapitalizm wyczerpania. Warszawa: Wydawnictwo Książka i Prasa.

Szahaj, A. (2014). Niesprawiedliwość a demoralizacja. W: Idem. Inny kapitalizm jest możliwy. Warszawa: Instytut Wydawniczy Książka i Prasa.

Thoburn, N. (2007). Patterns of Production. Cultural Studies after Hegemony. Theory, Culture \& Society 24(3).

Turner, S.P. (2003). Liberal Democracy 3.0. Civil Society in Age of Experts. London: SAGE Publications. 